\title{
RESEARCH
}

Open Access

\section{Production and marketing problems facing olive farmers in North Sinai Governorate, Egypt}

Tamer Gamal Ibrahim Mansour ${ }^{1 *}$ D, Mohamed Abo El Azayem', Nagwa El Agroudy ${ }^{1}$ and Salah Said Abd El-Ghani ${ }^{1,2}$

\begin{abstract}
Background: Although North Sinai Governorate has a comparative advantage in the production of some crops as olive crop, which generates a distinct economic return, whether marketed locally or exported. This governorate occupies the twentieth place for the productivity of this crop in Egypt. The research aimed to identify the most important production and marketing problems facing olive farmers in North Sinai Governorate. Research data were collected through personal interviewing questionnaire with 100 respondents representing $25 \%$ of the total olive farmers at Meriah village from October to December 2015.
\end{abstract}

Results: Results showed that there are many production and marketing problems faced by farmers. The most frequent of the production problems were the problem of increasing fertilizer prices (64\% of the surveyed farmers), and the problem of irrigation water high salinity (52\% of the respondents). Where the majority of the respondents mentioned that these problems are the most important productive problems they are facing, followed by problems of poor level of extension services (48\%), high cost of irrigation wells (47\%), difficulty in owning land (46\%), and lack of agricultural mechanization (39\%), while the most important marketing problems were the problem of the exploitation of traders (62\%), the absence of agricultural marketing extension (59\%), the high prices of trained labor to collect the crop (59\%), and lack of olive presses present in the area (57\%).

Conclusions: In spite of the efforts exerted by the Agricultural Extension Agency in the Governorate of North Sinai to assist olive farmers and raise their knowledge and skills level in relation to this crop, and despite the fact that this Governorate has a comparative advantage in terms of cultivated area and the quality of the final product, olive farmers face many production and marketing problems such as increasing fertilizer prices, irrigation water high salinity, poor level of extension services, high cost of irrigation wells, absence of agricultural marketing extension, and lack of agricultural mechanization. So that agricultural extension as a free educational service should assist farmers through targeted extension programs aimed at guiding them in the best way to address and overcome these problems.

Keywords: Farmers, Marketing, North Sinai, Olive, Problems, Production

\footnotetext{
* Correspondence: Tamer_baz@yahoo.com

${ }^{1}$ Agricultural Economic Department, National Research Centre, El Buhouth St.,

Dokki, Giza 12622, Egypt

Full list of author information is available at the end of the article
} 


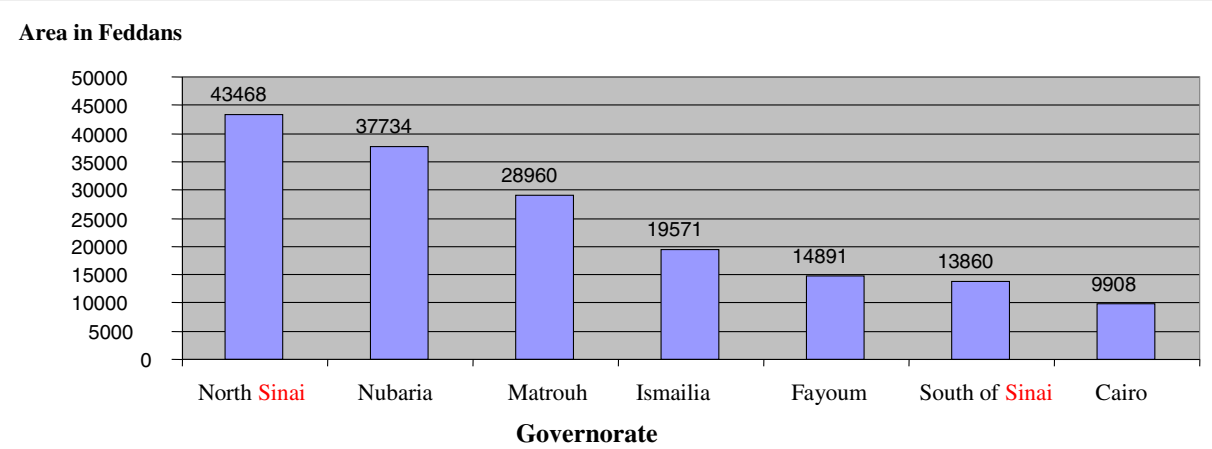

Fig. 1 Governorates and regions according to the cultivated area of olive in 2012. Source: Abstract of the Agricultural Economy Bulletin, Table (96), Central Administration of Agricultural Economics, Economic Affairs Sector, Ministry of Agriculture and Land Reclamation, Giza, 2013, p. 332

\section{Background}

Egypt has a competitive advantage in producing olive and olive oil because of its relatively stable climate and its commercial site which is distinctive for the areas of producing the crop, especially it occupies the eighth place in the global ranking of the countries producing olive oil and the third place among the countries producing table olive, as it contributes by about $11.5 \%$ of world production. The crop is planted for the purpose of producing olive oil by $10 \%$, and about $90 \%$ are for pickling (Bayoumi et al. 2014).

Although North Sinai Governorate has a comparative advantage in the production of some crops such as olive crop, which generates a distinct economic return, whether marketed locally or exported, as North Sinai is the largest region of the Arab Republic of Egypt in terms of area planted with olives, this area in 2012 is about 43,468 feddan. However, this governorate occupies the twentieth place for the productivity of this crop (Fig. 1). (Agricultural Economics Bulletin 2013).

The olive area in the Governorate has increased from 28,309 Feddan in 2008 to 43,468 Feddan in 2012, but the average productivity of the crop fell from 3.88 tons/ Feddan in 2008 to 2.29 tons/Feddan in 2012, which was the lowest productivity, compared to the average productivity in other governorates and occupied the twentieth place for the productivity of this crop (Fig. 2). (Agricultural Economics Bulletin 2008, p. 355 and 2013, p. 332).

The decrease in the average yield of the olive crop in North Sinai may be due to several reasons, including the existence of some problems facing farmers in the field of production and marketing Therefore, this study aims at identifying the most important production and marketing problems facing olive farmers in North Sinai Governorate and placing these problems in front of agricultural extension, in order to help farmers deal with these problems because the philosophy of agricultural extension is to help people to help themselves change their intellectual, operational, and sensory behavior to cope with their life problems in order to raise their economic and social status as a result of this behavioral change (Omar 1992). The farmer is the main focus of agricultural extension based on the philosophy of the extension system which is to

Productivityton per feddan

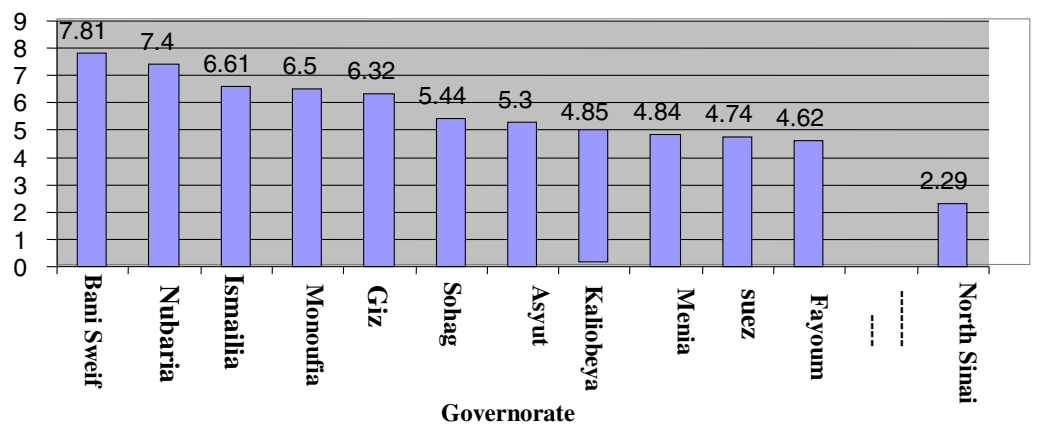

Fig. 2 The productivity of the olive crop in 2012. Source: Abstract of the Agricultural Economy Bulletin, Table (96), Central Administration of Agricultural Economics, Economic Affairs Sector, Ministry of Agriculture and Land Reclamation, Giza, 2013, p. 332 
Table 1 Olive areas in North Sinai Governorate for the 2013/ 2014 season

\begin{tabular}{lcll}
\hline Center (district) & Olive area & Center (district) & Olive area \\
\hline Arish & 7607 & Bir al-Abd & 9818 \\
Sheikh Zwaid & 4930 & Alhasana & 1390 \\
Rafah & 6296 & Nikhil & 547 \\
Total & 30,588 & & \\
Fruitful area & 16,939 & & \\
\hline
\end{tabular}

Source: Agricultural Administration in Bir al-Abd, July 2015

"Help farmers to help themselves" (Terblanché 2008). Agricultural extension is an educational process with the aim of conveying useful information for rural producers and changing their insight, knowledge, attitude, and skills in order to access better life for their family and society (Abedi et al. 2011).

\section{Purpose of the study}

The objectives of the study are to:

1. Describe the characteristics of respondents and their farms.

2. Identify the most important production and marketing problems facing olive farmers in North Sinai Governorate.

\section{Methods}

This study was based on the social survey method as the most commonly used descriptive research pattern; this research was conducted in North Sinai governorate. Due to the large area of the governorate, the largest center has been selected in terms of area cultivated with olives. The center of Bir al-Abd (9818 feddan) Table 1. The same criterion was chosen for the largest village in this

Table $\mathbf{2}$ Characteristics of participating farmers and their farms

\begin{tabular}{|c|c|c|c|c|c|}
\hline Characteristics & & No. farmers & Percentage \% & Mean & Std. \\
\hline \multirow[t]{4}{*}{$\overline{\text { Age }}$} & Young ( $<38$ years $)$ & 28 & 28 & & \\
\hline & Middle (38 to 50 years) & 47 & 47 & 44.5 & 9.5 \\
\hline & Old (> 50 years) & 25 & 25 & & \\
\hline & Illiterate & 22 & 22 & & \\
\hline \multirow[t]{3}{*}{ Education } & Primary education & 8 & 8 & & \\
\hline & Intermediate & 51 & 51 & & \\
\hline & University & 19 & 19 & & \\
\hline \multirow[t]{2}{*}{ Farm work time } & Full-time & 13 & 13 & & \\
\hline & Part-time & 87 & 87 & & \\
\hline \multirow{3}{*}{$\begin{array}{l}\text { Agricultural area } \\
\text { planted with olives }\end{array}$} & Less than feddan & 30 & 30 & 1.7 & 1.3 \\
\hline & feddan-less than 2 feddan & 26 & 26 & & \\
\hline & 2 feddan and more & 44 & 44 & & \\
\hline \multirow[t]{3}{*}{ Average productivity } & Less than a ton & 4 & 4 & & \\
\hline & Ton-less than 2 tons & 44 & 44 & 1.94 & 0.4 \\
\hline & 2 tons and more & 52 & 52 & & \\
\hline \multirow{3}{*}{$\begin{array}{l}\text { Farm experience in } \\
\text { olive cultivation (years) }\end{array}$} & Less than 16 years old & 52 & 52 & & \\
\hline & 16-less than 27 years & 29 & 29 & 17.6 & 8.8 \\
\hline & 27 years and over & 19 & 19 & & \\
\hline \multirow[t]{3}{*}{ Organizational participation } & $\begin{array}{l}\text { Low participation } \\
\text { (less than } 6 \text { degrees) }\end{array}$ & 76 & 76 & & \\
\hline & $\begin{array}{l}\text { Medium participation } \\
\text { (6-10 degrees) }\end{array}$ & 21 & 21 & 3.4 & 2.2 \\
\hline & $\begin{array}{l}\text { High participation } \\
\text { (more than } 10 \text { degrees }\end{array}$ & 3 & 3 & & \\
\hline \multirow[t]{3}{*}{$\begin{array}{l}\text { Altitude towards } \\
\text { agricultural extension }\end{array}$} & $\begin{array}{l}\text { Negative } \\
\text { (less than } 17 \text { degree) }\end{array}$ & 33 & 33 & & \\
\hline & $\begin{array}{l}\text { A neutral } \\
\text { (17-less than } 24 \text { degree) }\end{array}$ & 30 & 30 & 20 & 6.4 \\
\hline & Positive (24 degree and more) & 37 & 37 & & \\
\hline
\end{tabular}


Table 3 Production problems facing olive farmers

\begin{tabular}{lll}
\hline Problems & & $\%$ \\
\hline 1 & High price of fertilizers & 64 \\
3 & High salinity of irrigation water & 52 \\
4 & Poor level of extension services & 48 \\
5 & High cost of irrigation through wells & 47 \\
6 & Difficulty owning land & 46 \\
7 & Lack of agricultural mechanization & 39 \\
8 & Lack of know-how in various production processes & 38 \\
9 & Rising prices of pesticides & 38 \\
10 & Rising soil salinity & 35 \\
11 & Lack of trained technical workers & 31 \\
12 & High cost of maintenance of irrigation networks & 28 \\
13 & High prices of suitable olive seedlings & 27 \\
14 & Lack of irrigation network requirements & 27 \\
15 & The spread of some pests and diseases & 27 \\
16 & Lake of government services to farmers & 25 \\
17 & Non-leveling of soil & 24 \\
18 & Lrregularity and insufficient rainfall & 22 \\
19 & The harmful effect of floods & 12 \\
\hline $504 c$ col suitable varieties and seedlings & 8 \\
\hline
\end{tabular}

Source: collected and calculated from the questionnaire form $N=100$

center (Al Meriah village), with a total area of 1310 feddan (530.14 ha) for the year 2015 (Agricultural Administration in Bir al-Abed: Arish Agriculture Directorate, Ministry of Agriculture and Land Reclamation, Unpublished). The research consists of all the olive crop farmers registered by the village agricultural cooperative association (400 respondents).

And because of the difficulty of collecting data from all the holders due to security conditions and problems in the governorate, a simple random sample was selected. Based on what some statisticians mentioned about the appropriate size of the sample if we want to choose a simple random sample with a high degree of accuracy from homogeneous study community, the sample appropriate size is $23 \%$ (Kheder, 2016), Therefore, the researchers chose a simple random sampling of $23 \%$ of the total farmers in the village ( 92 farmers) that were increased to 100 farmers to facilitate the conduct of statistical analysis. Data collection tool was a questionnaire, and the field data were collected from October to December 2015 through a personal interview with the respondents.

\section{Results and discussion \\ Results}

First: description of the research sample

Characteristics of participating farmers and their farms summarized in Table 2 showed that $47 \%$ of respondents fall in the middle age group (38 to 51 ) years, $51 \%$ of them had an intermediate education qualification. The high percentage of respondents with intermediate or university qualifications is an opportunity for agricultural extension in the region if there is the will to deal with a more educated audience with the ability to learn and absorb the new in agriculture. Results show that

Table 4 Marketing problems facing olive farmers

\begin{tabular}{lll}
\hline Problems & & $\%$ \\
\hline 1 & Exploitation of traders & 62 \\
3 & The absence of marketing extension & 59 \\
4 & High prices of trained labor to collect the crop & 59 \\
5 & Lack of olive presses & 57 \\
6 & Lack of suitable packaging for olive & 44 \\
7 & The olive presses are far from the farm \\
8 & Lack of marketing information on quantities traded in the markets and ways of production distributing \\
9 & Delay the process of squeezing because of the quantities are relatively large than presses capacity \\
10 & Lack of trained labor to collect the crop & 38 \\
11 & Lack of fitted warehouses & 38 \\
12 & Production areas far from markets & 32 \\
13 & High transport cost & 30 \\
14 & Lack of information on how to Group marketing \\
15 & High percentage of losses during collection \\
16 & Reliance on traditional methods of collection & 30 \\
\hline
\end{tabular}

Source: collected and calculated from the questionnaire form $N=100$ 
$87 \%$ were part-time agricultural workers, $44 \%$ of them had agricultural area planted with olives ( 2 feddan and more) and it is a relatively large area allowing the farmer to experiment with the new ideas and modern agricultural methods in the production and marketing of the olive crop, and $52 \%$ of them had average productivity 2 tons and more. The maximum yield of the olive harvest in the surveyed farmers did not exceed 2.7 tons/fed. This low productivity requires the extension apparatus in the region to increase the level of production by providing more educational activities and programs aimed at raising the average productivity of the crop. The degree of social participation of the majority of farmers respondents (76\%) was low, and only $37 \%$ of respondents had a positive attitude toward agricultural extension which requires the extension staff to play a more active role in changing the negative and neutral agricultural attitude toward agricultural extension (Table 2).

\section{Second: the most important production and marketing problems facing olive farmers in North Sinai Governorate}

The results in Tables 3 and 4 indicated that there are many production and marketing problems faced by farmers. The most frequent of the production problems were increasing fertilizer prices (64\% of the surveyed farmers) and irrigation water high salinity (52\% of the respondents). Where the majority of the respondents mentioned that these problems are the most important productive problems facing them, followed by problems of poor level of extension services (48\%), high cost of irrigation wells (47\%), difficulty in owning land (46\%), and lack of agricultural mechanization (39\%), while the most important marketing problems were the problem of the exploitation of traders (62\%), the absence of marketing extension (59\%), the high prices of trained labor to collect the crop (59\%), and lack of olive presses present in the area.

\section{Discussion}

The previous results show a decrease in the productivity of the olive harvest in North Sinai compared to many other regions and governorates. This low productivity requires the extension apparatus in the region to increase the level of production by providing more educational activities and programs aimed at raising the average productivity of this important crop; agricultural extension should also help farmers to overcome the most important productive problems facing them, which were increasing fertilizer prices, irrigation water high salinity, poor level of extension services, and high cost of irrigation wells. In addition to the most important marketing problems which were exploitation of traders, the absence of marketing extension and lack of marketing information on quantities traded in the markets and ways of production distributing.

\section{Conclusions}

In spite of the efforts exerted by the Agricultural Extension Agency in the Governorate of North Sinai to assist olive farmers and raise their knowledge and skilled level in relation to this crop, and despite the fact that this Governorate has a comparative advantage in terms of cultivated area and the quality of the final product, olive farmers face many production and marketing problems such as increasing fertilizer prices, irrigation water high salinity, poor level of extension services, high cost of irrigation wells, absence of marketing extension, and lack of agricultural mechanization. Agricultural extension as a free educational service should assist farmers through targeted extension programs aimed at guiding them to the best way to address and overcome these problems.

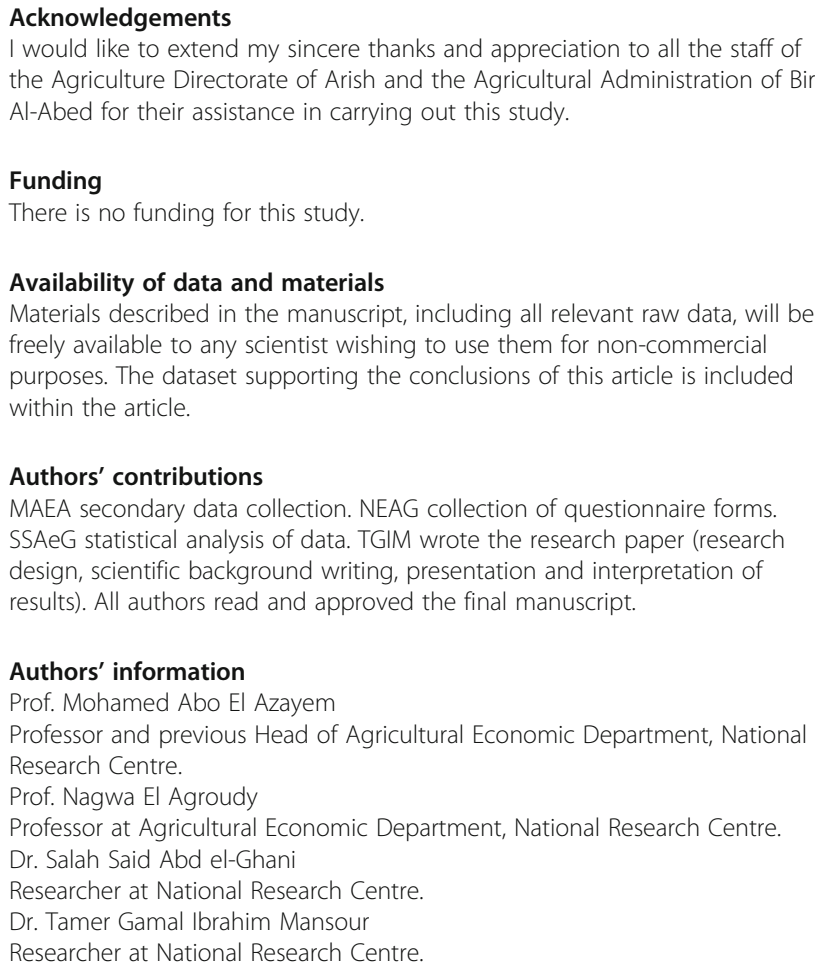

Authors' information

Prof. Mohamed Abo El Azayem

Professor and previous Head of Agricultural Economic Department, National Research Centre.

Prof. Nagwa El Agroudy

Professor at Agricultural Economic Department, National Research Centre.

Dr. Salah Said Abd el-Ghani

Researcher at National Research Centre.

Dr. Tamer Gamal Ibrahim Mansour

Researcher at National Research Centre.

Ethics approval and consent to participate

All participants in the study know the purpose and participated in it voluntarily.

Consent for publication

Not applicable.

Competing interests

The authors declare that they have no competing interests.

\section{Publisher's Note}

Springer Nature remains neutral with regard to jurisdictional claims in published maps and institutional affiliations. 


\section{Author details}

'Agricultural Economic Department, National Research Centre, El Buhouth St. Dokki, Giza 12622, Egypt. '2Department of Economics, Faculty of Economics and Administrative Sciences, Imam Muhammad bin Saud Islamic University, Riyadh, Saudi Arabia.

Received: 9 June 2018 Accepted: 5 April 2019

Published online: 24 April 2019

\section{References}

Abedi M, Mohammad SA, Sharareh K (2011) Role of agricultural extension and education on rural women's trends toward micro-credits programs. Afr J Bus Manag 5(15):6579-6585. https://doi.org/10.5897/AJBM11276. Available online at: https://academicjournals.org/journal/AJBM/article-abstract/8A2E44D14874 Agricultural Economics Bulletin, Central Administration of Agricultural Economics, Economic Affairs Sector, Ministry of Agriculture and Land Reclamation, 2013. Giza

Agricultural Economics Bulletin, Central Administration of Agricultural Economics, Economic Affairs Sector, Ministry of Agriculture and Land Reclamation, 2008. Giza

Bayoumi H, Zaghloul EA, Al-Gebaly MR, Abd el- Ghani SS (2014) An economic study of olive crop in North Sinai governorate. Middle East J Agric Res 3(4): 994-1001available at: http://www.curresweb.com/mejar/mejar/2014/9941001

Kheder Al 2016. Soft rules in the selection of sample size: (Alouka). Available in https://www.alukah net/web/khedr/0/51829/. Accessed 2 May 2015

Omar AM (1992) Contemporary agricultural extension. Egypt for Scientific Services, Cairo

Terblanché SE (2008) Towards an improved agricultural extension service as a key role player in the settlement of new farmers in south Africa. S Afr J Agric Ext 37:58-84 p 64. Available at www.scielo.org.za/pdf/sajae/v37n1/05

\section{Submit your manuscript to a SpringerOpen ${ }^{\odot}$ journal and benefit from:}

- Convenient online submission

- Rigorous peer review

- Open access: articles freely available online

- High visibility within the field

- Retaining the copyright to your article

Submit your next manuscript at $\boldsymbol{\nabla}$ springeropen.com 